\title{
PENGGUNAAN ALAT PERAGA SULINGPUSLING PADA MATERI SUDUT KELILING DAN SUDUT PUSAT LINGKARAN
}

\author{
Lilik Firdayati \\ SMP Negeri 3 Metro \\ E-Mail :firdayatililik@gmail.com
}

Received 11 August 2018; Received in revised form 17 September 2018; Accepted 24 September 2018

\begin{abstract}
Objective of study was to determine students' learning pattern in understanding angle around the circle and center corner of the circle concepts through teaching aids' suling and pusling' and also to know students' activities at the instruction. The advantages of teaching aids is to motivate students learning, so that they will be more selfconfident in finding concrete mathematics concepts, moreover, the instructional activity will be more enjoyable. Research method was Research and Development $(R$ and $D)$. The result of study showed that 'suling ang pusling' teaching aids could ease students grabbed the concepts i.e the relation betwen angles around the circle and center corner of The circle. It was shown from observation sheet results of students activities that their activities through this teaching aids could be at very active level with average students' score $80.86 \%$
\end{abstract}

Keywords: Learning teaching aids; Sulingpusling

\section{PENDAHULUAN}

Materi pelajaran hubungan antara sudut keliling dan sudut pusat lingkaran merupakan materi baru di kelas VIII SMP semester dua. Dalam hal ini guru belum secara maksimal dalam menggunakan alat peraga sebagai alat bantu pembelajaran. Bahkan tidak sedikit guru yang tidak menggunakan alat peraga sama sekali. Guru selama ini lebih mengutamakan kegiatan pembelajaran yang berorientasi pada ranah kognitif, dan sering meninggalkan ranah lain yaitu afektif dan psikomotor siswa, sehingga perubahan kedewasaan siswa setelah mengikuti serangkaian pembelajaran menjadi kurang maksimal.

Pembelajaran adalah upaya untuk membelajarkan siswa. Dalam pengertian ini secara nyata dalam pembelajaran terdapat upaya untuk membelajarkan siswa agar siswa dapat memahami ilmu-ilmu yang diberikan. Itulah sebabnya dalam belajar siswa seharusnya tidak hanya berinteraksi dengan guru sebagai salah satu sumber belajar, tetapi mungkin berinteraksi dengan keseluruhan sumber belajar yang dipakai untuk mencapai tujuan pembelajaran yang diinginkan sehingga siswa dapat memahami konsep-konsep yang dipelajari dan dapat mengaplikasikan ilmu-ilmunya dalam kehidupan sehari-hari.

Untuk memperoleh hasil pembelajaran yang maksimal, tentunya pembelajaran juga harus berjalan maksimal, mulai dari materi yang diberikan dan respon dari siswa untuk menerima pelajaran. Selain itu, dalam proses pembelajaran Matematika, siswa perlu diberi kesempatan untuk mengembangkan potensi yang dimiliki. Peran guru sangat dituntut untuk membantu siswanya dalam mencapai hasil belajar yang maksimal.

Dalam proses pembelajaran Matematika, seharusnya dapat langsung diamati dan diaplikasikan dalam kehidupan sehari-hari. Tetapi fakta yang terjadi dikalangan siswa timbul kesan bahwa Matematika adalah pelajaran yang membingungkan siswa. Padahal mempelajari Matematika tidak sekadar hafal rumus, tetapi juga

\section{0 | AKSIOMA}

Jurnal Pendidikan Matematika FKIP Univ. Muhammadiyah Metro 
penerapan konsep-konsep pada kehidupan sehari-hari. Selain itu guru menyampaikan materi secara monoton yaitu ceramah atau kegiatan yang tidak melibatkan keaktifan siswa dan disampaikan secara menegangkan sehingga banyak siswa takut dan kurang suka untuk mempelajari materi-materi Matematika.

Belum maksimalnya pembelajaran Matematika ini terlihat dan terbukti pada pembelajaran Matematika materi lingkaran kelas VIII SMP Negeri 3 Metro. Ketika guru memberikan pertanyaan sebagai pengulangan materi, belum ada siswa yang menjawab. Ketika guru memberikan kesempatan untuk bertanya, respon siswa sangatlah minim, sehingga kondisi pembelajaran terasa sepi dan membosankan. Kondisi seperti ini sering terjadi di kelas terutama pada pembelajaran Matematika, karena pembelajaran berlangsung kurang menarik.

Proses pembelajaran pada dasarnya merupakan proses komunikasi sehingga media yang digunakan dalam pembelajaran disebut media pembelajaran. Sebelum memahami pengertian alat peraga perlu memahami terlebih dahulu pengertian media, karena alat peraga merupakan media. Penggunaan media secara kreatif dapat memperlancar dan meningkatkan efesiensi pembelajaran sehingga tujuan pembelajaran dapat tercapai. Media pembelajaran juga sebagai sarana mewujudkan situasi pembelajaran yang efektif, merangsang siswa agar dapat menangkap tujuan dan bahan ajar lebih mudah dan lebih cepat, dan dapat meningkatkan kualitas proses pembelajaran (Hariastuti, 2018)

Menurut (Sumiati, 2009) menyatakan bahwa media adalah segala sesuatu yang dapat menyalurkan informasi dari sumber informasi kepada penerima informasi. Penggunaan media pembelajaran dalam proses belajar mengajar sangat dianjurkan untuk mempertinggi kualitas pembelajaran. Untuk menjadikan pembelajaran matematika lebih baik dari pembelajaran sebelumnya dimana hanya menjelaskan materi tanpa mengaitkan materi dengan kehidupan disekitar siswa. pembelajaran yang menekankan kepada proses keterlibatan siswa secara penuh untuk dapat menemukan materi yang dipelajari dan menghubungkannya dengan situasi kehidupan nyata (Safitri, 2017)

Kemudian menurut (Guntoro, 2010) Alat peraga adalah alat bantu pembelajaran yang digunakan pendidik dalam menyampaikan bahan pendidikan/ Pengajaran, yang berfungsi membantu dan meragakan sesuatu dalam proses pembelajaran. Alat peraga disusun berdasarkan prinsip bahwa pengetahuan yang ada pada setiap manusia itu diterima atau ditangkap melalui pancaindera. Semakin banyak indera yang digunakan untuk menerima sesuatu, maka semakin banyak dan semakin jelas pula pengetahuan yang diperoleh. Dengan perkataan lain, alat peraga ini dimaksudkan untuk mengerahkan indera sebanyak mungkin kepada suatu objek sehingga mempermudah persepsi.

Siswa yang tahap berfikirnya masih pada tahap konkret mengalami kesulitan untuk memahami operasi logis dan konsep pembelajaran tanpa alat bantu dengan alat peraga. Penggunaan alat peraga dalam pembelajaran, siswa diberi kesempatan untuk memanipulasi benda-benda konkret/alat peraga, sehingga siswa langsung dapat berfikir bagaimana, serta pola apa yang terdapat dalam benda-benda yang sedang diperhatikannya.

Dalam memahami konsep matematika yang abstrak, anak memerlukan alat peraga seperti benda 
benda konkrit (riil) sebagai perantara atau visualisasinya. Dalam pembelajaran matematika, penggunaan alat peraga juga dapat meningkatkan motivasi belajar siswa (Annisah, 2014)

Alat peraga difungsikan sebagai jembatan untuk menyampaikan informasi dari guru kepada siswa dengan tepat. Penggunaan media yang berupa alat peraga, yaitu sebagai alat visualisasi untuk memahami konsep abstrak. Diharapkan juga dengan bantuan alat peraga dalam proses pembelajaran ,siswa akan termotivasi, senang, terangsang, dan tertarik. Tetapi kegunaan alat peraga tersebut akan gagal bila konsep abstrak dari representasi kongkrit itu tidak tercapai. Untuk itu perlu dirancang media berupa alat peraga sebagai alat bantu memahami konsep dasar tentang sudut keliling dan sudut pusat lingkaran. Penulis mencoba merancang alat peraga yang membantu konsep sudut keliling dan sudut pusat lungkaran dengan menggunakan sulingpusling. Alat peraga matematika ini sengaja dirancang, dibuat, dan disusun untuk membantu menanamkan atau mengembangkan konsep-konsep atau prinsip-prinsip dalam matematika, terutama materi sudut keliling dan sudut pusat lingkaran.

Hal ini dibuktikan dengan hasil ulangan dan ketuntasan belajar yang dicapai antara 50\% - 60\%. Keterbatasan sarana dan prasarana yang disediakan juga membuat tidak maksimalnya pembelajaran yang dilakukan oleh guru dan siswa. Untuk itu, diperlukan cara agar siswa dapat lebih aktif dalam pembelajaran, memahami, mengingat, dan menguasai konsep Matematika. Maka dari itu sangatlah dibutuhkan hal yang bersifat empiris untuk mempelajarinya dan seharusnya disampaikan senyata mungkin, agar materi-materi bisa tergambar dan terekam dalam memori siswa. Pembelajaran yang bersifat empiris bisa dilaksanakan dengan melaksanakan pembelajaran matematika dengan menggunakan alat peraga matematika dalam pembelajaran.

(Indrawati, 2009) menjelaskan bahwa dalam pembelajaran, siswa dapat memperoleh pengalaman langsung, sehingga dapat menambah kekuatan untuk menerima, menyimpan, dan menerapkan konsep yang telah dipelajarinya. Dengan demikian, siswa perlu diberikan latihan untuk dapat menanamkan sendiri berbagai konsep yang dipelajari secara menyeluruh, bermakna, otentik dan aktif. Kemudian dengan penggunaan alat peraga siswa akan lebih tertarik dan termotivasi untuk belajar karena siswa jarang menerima materi dengan penggunaan alat peraga, jadi hal ini merupakan hal baru bagi siswa. Alat peraga yang telah dikembangkan adalah alat peraga matematika sulingpusling.

Tujuan penelitian ini adalah untuk : 1) Mengetahui perkembangan pola pikir siswa dalam pemahaman konsep sudut keliling dan sudut pusat lingkaran dengan menggunakan alat peraga sulingpusling. 2) Mengetahui keaktifan siswa pada pembelajaran dengan menggunakan alat peraga sulingpusling sebagai media penunjang dalam menjelaskan materi sudut keliling dan sudut pusat lingkaran.

\section{METODE PENELITIAN}

Penelitian dilaksanakan di SMP Negeri 3 Metro pada semester genap tahun pelajaran 2016/2017. Subyek penelitian adalah siswa SMP N 3 kelas VIII secara acak untuk uji coba skala kecil yang berjumlah 6 orang dan kelas VIII H SMP N 3 Metro untuk uji coba skala besar dengan jumlah siswa 32 orang.

\section{2 | AKSIOMA}




\begin{abstract}
Metode penelitian dan pengembangan adalah metode penelitian yang digunakan untuk menghasilkan produk tertentu, dan menguji keefektifan produk tersebut. Penelitian dan pengembangan $(R \& D)$ adalah suatu proses yang dipakai untuk mengembangkan dan memvalidasi produk pendidikan. Untuk menghasilkan produk tertentu digunakan penelitian yang bersifat analisis kebutuhan dan untuk menguji keefektifan produk supaya dapat berfungsi di masyarakat luas, maka diperlukan penelitian untuk menguji keefektifan produk tersebut (Setiyosari, 2012)
\end{abstract}

Langkah-langkah penelitian yang ditempuh dalam penelitian ini sesuai dengan alur kerja pada metode penelitian \& pengembangan dalam (Sugiyono, 2011): Potensi dan Masalah, penelitian diawali dari potensi atau masalah yang dapat menimbulkan kesenjangan antara kenyataan dan teori yang ditemukan di sekolah. Pada tahap ini dilakukan identifikasi masalah tentang pembelajaran Matematika di SMP, dalam hal ini adalah SMP N 3 Metro. Dalam pembelajaran masih belum maksimal dalam melibatkan siswa untuk memahami konsep yang harus dipelajari. Selain itu pembelajaran matematika belum menggunakan alat peraga yang menarik, sehingga motivasi siswa masih rendah.

Mengumpulkan Informasi, sebelum melakukan penelitian pengembangan, diadakan wawancara untuk mengumpulkan data yang dilakukan dengan cara mencari informasi dari guru lain dan siswa tentang pelaksanaan pembelajaran matematika. Data ini untuk memperkaya informasi dalam menyusun model, metode pembelajaran dan alat peraga yang bisa digunakan.
Desain Produk, tahap ini adalah tahapan dalam membuat rancangan produk yang akan dihasilkan. Pada tahap ini kegiatan yang akan dilakukan yaitu merancang bentuk alat peraga sulingpusling. Alat Peraga yang dilengkapi dengan Lembar Kerja Siswa, dan Instrumen pengumpulan data. Hasil rancangan berupa prototipe I dan tahap selanjutnya akan divalidasi oleh ahli.

Validasi Desain, validasi desain dilakukan oleh pakar media, menggunakan instrumen validasi pakar yang telah disesuaikan. Validasi desain merupakan proses kegiatan untuk menilai apakah desain produk, dalam hal ini alat peraga sulingpusling valid atau layak menurut pakar. Pakar yang akan memvalidasi dan mengevaluasi alat peraga ini terdiri terdiri dari empat pakar, yaitu bapak Joko Widodo, S.Pd,M.Pd beliau sebagai Kepala Sekolah SMP N 7 Metro, juga sebagai guru inti pada MGMP Matematika SMP Kota Metro telah berpengalaman tentang media, Ibu Sri Endang Supriyatun, S.Pd guru SMP N 4 Metro dan guru inti pada MGMP Matematika SMP Kota Metro, Ibu Ruliasa Sofia, S.Pd guru SMP N 4 Metro, Ibu Murtati,M.Pd guru SMP N 2 Metro.

Dari ahli-ahli ini diperoleh masukan berupa saran-saran perbaikan produk yang dikembangkan, baik dari komponen efektivitas, komponen efisiensi, dan komponen daya tarik penggunaan alat peraga: Perbaikan Desain, memperbaiki kekurangan dan menyempurnakan produk berdasarkan hasil validasi pakar. Kemudian dikembalikan kepada validator untuk dinyatakan valid atau layak, sebagai prototipe II, Uji coba produk, uji coba awal dilakukan pada skala kecil. Uji coba dilakukan untuk mendapatkan informasi dari siswa apakah alat peraga sulingpusling ini dapat digunakan siswa dengan mudah. Data ini digunakan 
sebagai data pendukung validasi produk. Subyek pada uji coba ini adalah 6 siswa dari kelas VIII SMP N 3 Metro tahun pelajaran 2016/2017 dengan ketentuan 2 siswa yang memiliki kemampuan tinggi, 2 siswa yang memiliki kemampuan sedang dan 2 siswa yang memiliki kemampuan rendah. Penentuan keenam siswa tersebut berdasarkan nilai ulangan harian materi sebelumnya.

Teknik yang dilakukan pada uji coba ini dengan cara membagikan alat peraga sulingpusling kepada siswa, satu alat peraga digunakan 3 siswa. Kemudian siswa diberi waktu untuk mempelajari alat peraga sesuai dengan petunjuk yang terdapat pada LKS. Setelah itu, siswa diminta untuk mengisi angket yang telah disediakan. Revisi Produk, merevisi hasil uji coba pemakaian dan menyempurnakan produk berdasarkan data-data dari hasil uji coba, kemudian dikembalikan lagi kepada validator untuk dinyatakan valid atau layak setelah diperbaiki, sebagai prototipe III. Kemudian ujicoba pemakaian

Setelah dilakukan uji coba skala kecil dan direvisi, maka selanjutnya dilakukan uji coba pemakaian pada kelompok besar. Uji coba pemakaian digunakan untuk mengetahui keaktifan siswa menggunakan alat peraga sulingpusling selama pembelajaran yang dinilai melalui observasi. Subyek pada uji coba skala besar ini adalah siswa kelas VIII H SMP N 3 metro tahun pelajaran 2016/ 2017.

Desain ujicoba pemakaian, menggunakan metode pretest-posttest atau before-after menurut (Sugiyono,2011).

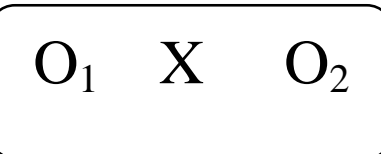

O1 : nilai pretest (sebelum diberi perlakuan)

$\mathrm{O} 2$ : nilai posttes (setelah diberi perlakuan)

$\mathrm{X}$ : perlakuan atau treatment

Revisi Produk, mengevaluasi hasil uji coba pemakaian dan menyempurnakan produk berdasarkan data-data dari hasil uji coba pemakaian. Hal ini dilakukan untuk penyempurnaan produk alat peraga sulingpusling. Sebagai produk akhir dalam penelitian berupa alat peraga sulingpusling pada materi sudut keliling dan sudut pusat lingkaran yang telah melalui validasi oleh pakar, uji coba pemakaian, dan perbaikan.

Instrumen data yang digunakan : 1) Lembar validasi alat peraga, instrumen ini digunakan untuk memperoleh data tentang penilaian pakar terhadap alat peraga sulingpusling. Hasil ini yang dijadikan dasar untuk mengetahui efektivitas, efisiensi dan daya tarik serta kreativitas penggunaan alat peraga. 2) Angket, angket digunakan untuk mengetahui tanggapan siswa terhadap kegiatan pembelajaran dengan alat peraga sulingpusling. Pengisian angket dilakukan setelah berakhirnya seluruh kegiatan pembelajaran. 3) Lembar Observasi, lembar observasi ini digunakan untuk mengamati aktivitas siswa dalam pembelajaran dengan menggunakan alat peraga sulingpusling. 4) Tes, tes digunakan untuk mengetahui hasil belajar siswa sebelum diberi perlakuan (pretest) dan setelah diberi perlakuan (posttest) serta ada atau tidaknya peningkatan hasil belajar setelah menggunakan alat peraga sulingpusling. Selanjutnya data yang didapatkan dari pretest dan posttest akan dihitung dan dianalisa untuk mengetahui peningkatan belajar siswa.

Analisis data yang digunakan : 1) data non tes, antara lain lembar validasi alat peraga, angket tanggapan siswa,

\section{4 | AKSIOMA}

Jurnal Pendidikan Matematika FKIP Univ. Muhammadiyah Metro 
lembar observasi aktivitas siswa. 2) data tes, data tes ini dianalisis menggunakan analisis n-gain. Analisis dilakukan untuk mengetahui peningkatan (gain) hasil belajar siswa setelah menggunakan alat peraga sulingpusling. a. Pemberian skor dan merubahnya dalam bentuk nilai. Analisis hasil tes dilakukan untuk mengetahui peningkatan hasil belajar siswa setelah menggunakan alat peraga sulingpusling. Skor setiap siswa dapat diperoleh dengan perhitungan

$$
\text { Skor }=\frac{\text { jawaban siswa benar }}{\text { skor maksimal }} \times 100
$$

Menghitung gain skor setiap butir soal semua subjek penelitian (siswa) Gain adalah selisih antara skor posttest dan skor pretest dibandingkan dengan selisih antara skor maximum dan skor pretest. Secara matematis dirumuskan (Wallen, 1993)

\section{HASIL PENELITIAN DAN PEMBAHASAN}

\footnotetext{
Dalam kegiatan pengembangan meliputi tahapan: perencanaan, pelaksanaan, dan evaluasi yang diikuti dengan kegiatan penyempurnaan sehingga diperoleh bentuk yang dianggap memadai. Terdapat banyak model pengembangan perangkat, salah satunya adalah model pengembangan perangkat menurut (Trianto, 2012), adalah model 4-D. Model ini meliputi empat tahap pengembangan, yaitu pendefinisian (define), perancangan (design), pengembangan (develop), dan pendiseminasian (disseminate). Pada penelitian ini arahnya adalah untuk menghasilkan suatu produk berupa alat peraga dan mengkaji dengan mengikuti alur tertentu. Penelitian yang diarahkan untuk menghasilkan produk, desain dan proses seperti ini diidentifikasi sebagai suatu penelitian pengembangan.
}

Alat peraga yang dikembangkan adalah sulingpusling, salah satu alat peraga yang digunakan untuk membuktikan besarnya sudut keliling dan sudut pusat lingkaran serta hubungan kedua sudut tersebut. Selain untuk membuktikan besar sudut keliling dan sudut pusat lingkaran, juga dapat digunakan untuk menjelaskan besarnya beberapa sudut keliling yang menghadap busur yang sama, sudut keliling yang menghadap diameter, dan sub bahasan selanjutnya yaitu besarnya sudut dari perpotongan dua tali busur di dalam lingkaran dan dua tali busur yang berpotongan di luar lingkaran.

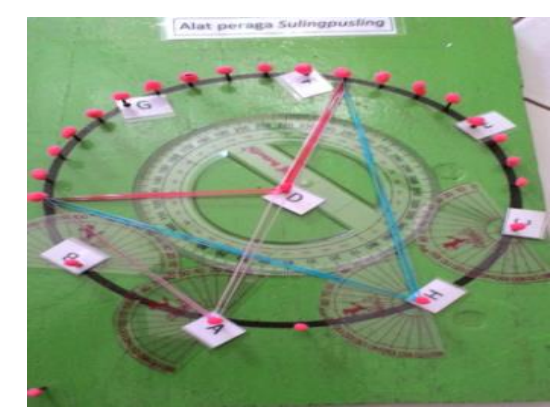

Gambar 1. Alat peraga sulingpusling

\section{Cara Penggunaan alat peraga sulingpusling :}

1) Untuk membuktikan hubungan sudut keliling dan sudut pusat lingkaran : Siapkan alat peraga sulingpusling, mengaitkan karet pada paku yang terdapat busur setengah lingkaran sebagai sudut keliling, dengan menghadap sebuah busur, mengaitkan karet pada paku yang berada di pusat lingkaran, sebagai sudut pusat lingkaran, dengan menghadap busur yang sama dengan sudut keliling, Mengamati besar sudut keliling dan besar sudut pusat melalui busur yang ada, untuk membuktikan hubungan antara sudut keliling dan sudut pusat lingkaran yang menghadap busur 
yang sama, dilakukan beberapa percobaan, sehingga siswa dapat sebuah kesimpulan

2) Membuktikan hubungan beberapa sudut keliling yang menghadap busur yang sama : mengaitkan karet pada paku yang terdapat busur setengah lingkaran, sehingga membentuk sudut keliling yang menghadap sebuah busur, mengaitkan karet lain pada paku yang terdapat busur setengah lingkaran, sehingga membentuk sudut keliling menghadap busur yang sama., engamati beberapa sudut keliling yang menghadap busur yang sama dengan busur yang ada, ari beberapa percobaan yang dilakukan, siswa dapat mengambil kesimpulan hubungan beberapa sudut keliling yang menghadap busur yang sama.

3) Membuktikan besar sudut keliling yang menghadap diameter lingkaran : mengaitkan karet pada paku yang terdapat busur setengah lingkaran, dan menghadap diameter lingkaran, dilakukan pada beberapa sudut keliling yang menghadap diameter lingkaran, mengamati ukuran beberapa sudut keliling tersebut, sehingga siswa dapat menyimpulkan besarnya beberapa sudut keliling yang menghadap diameter lingkaran.

Sudut keliling lingkaran adalah sudut pada lingkaran yang dibentuk oleh dua tali busur dan sudut pusat lingkaran adalah sudut pada lingkaran yang dibentuk oleh dua buah jari-jari dan menghadap suatu busur lingkaran, (Agus, 2007)

Alat peraga sulingpusling ini di proses, karena selama ini untuk menyampaikan konsep sudut keliling dan sudut pusat lingkaran dengan media gambar belum memberikan pengalaman siswa dengan maksimal, karena ternyata siswa masih merasa sulit untuk menjelaskan bagaimana menentukan hubungan sudut keliling dan sudut pusat lingkaran. Dari hal tersebut terinspirasi untuk membuat alat peraga yang dapat bermanfaat dalam pembelajaran lingkaran.

Uji kelayakan alat peraga merupakan rerata penilaian dari beberapa ahli media. Penilaian dari ahli media cukup dilakukan sekali saja, karena penilaian sudah mendapat kriteria layak dan sangat layak, sehingga saran atau masukan revisi tetap dilakukan namun tidak diujikan kelayakannya kembali. Penilaian uji kelayakan materi juga merupakan rerata penilaian dari beberapa ahli materi. Penilaian dari ahli materi juga cukup dilakukan sekali saja, karena penilaian sudah mendapat kriteria sangat layak, sehingga saran atau masukan revisi tetap dilakukan namun tidak dinilaikan lagi.

Bagian produk yang mendapat saran revisi berdasarkan uji kelayakan dari ahli media dan ahli materi dan hasil validasi antara lain : 1) Ukuran papan lebih dilebarkan; 2) Busur dibuat transparan dan supaya dimasukkan ke dalam paku untuk ketepatan pengukuran; 3) Peletakan paku dibuat tidak terlalu rapat agar perputaran busur lebih lapang; 4) Berikan nama pada setiap alat peraga; 5) Paku harap diberi pengaman supaya tidak tajam.

Setelah dilakukan revisi dilanjutkan uji coba skala kecil kepada 6 siswa. Uji coba skala kecil ini bertujuan untuk mengetahui kemudahan penggunaan. Penentuan keenam siswa tersebut berdasarkan pertimbangan guru. Data kemudahan penggunaan diperoleh dari angket tanggapan siswa. Pada uji coba produk skala kecil, alat peraga sulingpusling dinilai oleh 6 orang siswa kelas VIII SMP N 3 Metro yang dipilih 
secara acak dengan ketentuan 2 siswa yang memiliki kemampuan tinggi, 2 siswa yang memiliki kemampuan sedang dan 2 siswa yang memiliki kemampuan rendah. Data yang diperoleh dari uji coba skala kecil ini berupa angket yang digunakan sebagai data pendukung validasi pakar.

Beberapa saran siswa pada tahap uji skala kecil ini diantaranya supaya busur lingkaran dan busur setengah lingkaran menggunakan yang transparan, sehingga karet bisa lebih terlihat jelas dan mempermudah untuk melihat garis sadutnya. Selain itu, paku harus dilindungi sehingga tidak tajam pada saat penggunaan. Berdasarkan masukan, pada alat peraga telah dilakukan revisi dengan mengganti busur busur transparan, dan paku diberi pengaman sehingga tidak lagi tajam. Tahap revisi akhir ini dilakukan sampai produk dinyatakan layak oleh ahli.

Setelah dilakukan uji coba skala kecil, dilanjutkan dengan uji coba pemakaian. Pada uji coba pemakaian diperoleh data hasil observasi aktivitas siswa dan data tes hasil belajar siswa dengan membandingkan hasil pretest dan posttest. Hasil observasi dan tes adalah sebagai berikut. 1) Observasi Aktivitas Siswa, untuk mengukur keaktifan siswa digunakan data yang dapat mengukur keaktifan siswa, yaitu melalui lembar observasi aktivitas siswa. Hasil analisis observasi aktivitas siswa terhadap pembelajaran menggunakan alat peraga sulingpusling. Rata-rata aktivitas siswa dalam pembelajaran dengan menggunakan alat peraga sulingpusling masuk dalam kategori aktif dengan rata-rata persentase $80,86 \%$. Kemudian siswa yang dikategorikan sangat aktif berjumlah 14 siswa dengan persentase $45,16 \%$ dan siswa yang dikategorikan aktif ada 17 siswa dengan persentase $54,84 \%$.
Dengan demikian alat peraga sulingpusling sangat membantu untuk meningkatkan motivasi belajar siswa yang ditunjukkan dengan tingginya aktivitas siswa dalam pembelajaran. 2) Analisis untuk menguji keefektifan alat peraga digunakan pula tes hasil belajar melalui pretest-posttest. yaitu menggunakan analisis n-gain untuk mengetahui peningkatan (gain) hasil belajar siswa.

Kelayakan alat peraga sulingpusling dinilai oleh ahli media dan ahli materi. Kelayakan alat peraga dinilai dua orang ahli media yaitu Zuni laya, S.Pd dan Sri Wahyuningsih, S.Pd keduanya guru matematika di SMP N 3 metro. Aspek penilaian media meliputi daya tahan komponen-kmponen alat peraga sulingpusling, Penggunaan alat peraga sulingpusling dalam pembelajaran, Menumbuhkan rasa ingin tahu siswa dalam belajar matematika, merangsang kedalaman berpikir siswa dalam pembelajaran, memotivasi belajar siswa, memperlihatkan daya tarik siswa, ketahanan dan keawetan alat peraga suling pusling, dan perawatan alat peraga sulingpusling.

Kelayakan alat peraga juga diniali oleh dua ahli materi yaitu Dewi Kartika, S.Pd dan Kurniati, S.Pd keduanya guru matematika SMP N 3 Metro. Aspek penilaian meliputi penyajian alat peraga sulingpusling sesuai dengan materi, Kesesuaian alat peraga sulingpusling dengan materi dan indikator pencapaian, kejelasan penyajian materi dengan alat peraga sulingpusling, dan materi disajikan sesuai dengan konsep.

Adapun kelayakan alat peraga sulingpusling juga dapat penilaian dari beberapa guru matematika dari segi efektivitas, efisiensi, daya tarik dan kreativitas, yaitu Murtati, M.pd (guru SMP N 2 Metro), Sri Endang 
Supriyatun, S.Pd (guru SMP N 4 Metro), Ruliana Sofia, S.Pd (guru SMP N 4 Metro), Joko Widodo, S.Pd, M.Pd (Kepala SMP N 7 Metro). Aspek penilaian meliputi komponen afektivitas antara lain pemilihan jenis alat peraga sulingpusling sebagai penunjang pembelajaran, Kesesuaian alat peraga sulingpusling sesuai dengan karakteristik materi, Kejelasan petunjuk penggunaan alat peraga sulingpusling dalam pembelajaran, kejelasan tampilan alat peraga sulingpusling untuk menunjang pencapaian pemahaman konsep.

Komponen efisiensi antara lain kemudahan penggunaan alat peraga sulingpusling dalam pembelajaran, efisiensi waktu pembelajaran menggunakan alat peraga sulingpusling. Dari komponen daya tarik dan kreativitas antara lain tampilan alat peraga sulingpusling dalam pembelajaran untuk menumbuhkan minat belajar dalam diri siswa, kreativitas penuangan ide dan gagasan dalam alat peraga sulingpusling.

Siswa sangat merespon baik pembelajaran matematika menggunakan alat peraga. Hal ini menunjukkan alat peraga memiliki peran pokok dan menjadi salah satu kebutuhan pokok dalam pembelajaran selain kebutuhan pokok yang lain. Respon yang diberikan oleh siswa merupakan bukti dengan alat peraga, konsep matematika dapat diterima siswa secara kongkrit yang biasanya materi matematika diterima siswa secara abstrak. Berdasarkan teori Piaget tampak bahwa pada awal, anak belajar melalui hal-hal yang konkret atau nyata dalam arti dapat diamati dengan menggunakan panca indera mereka.

Oleh karena itu, untuk memahami konsep matematika yang bersifat abstrak, anak memerlukan benda-benda konkret (Guntoro, 2010). Hal ini memberikan arti bahwa alat peraga mempunyai peran sangat penting dalam proses pembelajaran, karena dengan penggunaan alat peraga yang tepat akan dapat membantu siswa mempermudah menyerap materi pelajaran.

Dengan demikian penggunaan alat peraga sulingpusling pada materi hubungan sudut keliling dan sudut pusat lingkaran meningkatkan motivasi dan semangat belajar, sehingga hasil belajar siswapun mengalami peningkatan. Sesuai data hasil belajar siswa, dapat disimpulkan bahwa alat peraga sulingpusling pada materi sudut keliling dan sudut pusat lingkaran untuk siswa SMP berpengaruh secara signifikan terhadap pembelajaran Matematika. Pengaruh signifikan ini ditunjukkan dengan adanya peningkatan hasil belajar siswa.

Hasil observasi aktivitas siswa digunakan untuk mengetahui keaktifan siswa dalam pembelajaran menggunakan alat peraga sulingpusling pada materi hubungan antara sudut keliling dan sudut pusat lingkaran, dan hasil observasi aktivitas siswa menunjukkan hasil yang positif. Persentase pada seluruh butir hasil observasi aktivitas siswa diperoleh ratarata sebesar $81,45 \%$ dengan kriteria sangat aktif. Aspek yang diamati selama observasi meliputi : Aktif bertanya, mampu menjawab pertanyaan, mampu menggunakan alat peraga, aktif diskusi, mampu bekerja sama, mampu memberikan pendapat, percaya diri. Kriteria sangat aktif pada pembelajaran dengan menggunakan alat peraga sulingpusling dapat dikatakan bahwa alat peraga efektif diterapkan pada pembelajaran materi hubungan sudut keliling dan sudut pusat lingkaran untuk siswa SMP. Aktivitas siswa mencapai sangat aktif dikarenakan siswa sudah termotivasi dalam mengikuti pembelajaran. Selain itu juga karena

\section{8 | AKSIOMA}

Jurnal Pendidikan Matematika FKIP Univ. Muhammadiyah Metro 
hasil validasi para pakar dan angket tanggapan siswa telah masuk kriteria sangat layak dan sangat baik. Respon positif dari siswa berpengaruh positif pula pada aktivitas siswa dalam pembelajaran karena siswa merasa tertarik dengan alat peraga yang digunakan dalam pembelajaran.

Secara keseluruhan dapat dipahami bahwa keaktifan siswa saat pembelajaran dengan menggunakan alat peraga sulingpusling sudah bisa dikatakan bagus, karena melihat kondisi siswa yang biasanya kurang bahkan tidak aktif dalam pembelajaran dapat meningkatkan aktivitasnya, hal ini diketahui berdasarkan hasil observasi selama pembelajaran menggunakan alat peraga sulingpusling. Selain itu kegiatan pembelajaran yang berlangsung dapat menumbuhkan sikap/kesan yang positif dan percaya diri siswa (afektif)

Pretest dilaksanakan sebelum proses pembelajaran dan posttest dilaksanakan setelah proses pembelajaran selesai. Penilaian dengan teknik tes dipilih karena tes pelaksanaannya di bawah pengawasan guru sehingga dapat diketahui kemampuan siswa secara individu. Nilai pretest dan posttest ini juga dijadikan sebagai salah satu penilaian kelayakan dari alat peraga yang dikembangkan dengan cara membandingkan hasil nilai pretest dan posttest. Apabila nilai pretest dan posttest mengalami kenaikan maka alat peraga yang dikembangkan layak digunakan, begitu pula sebaliknya apabila ternyata nilai posttest lebih rendah dari nilai pretest maka dapat dikatakan alat peraga yang dikembangkan tidak layak digunakan karena tidak memberikan dampak positif terhadap hasil belajar siswa.
Tabel 1. Analisis hasil pretest - posttest $n$-gain siswa

\begin{tabular}{lcccc}
\hline Komponen & pretest & posttest & $\begin{array}{c}\text { Peningkatan } \\
\text { (gain) }\end{array}$ & Kriteria \\
\hline $\begin{array}{l}\text { Nilai Rata- } \\
\text { rata }\end{array}$ & 56,09 & 86,76 & 0,70 & Tinggi \\
\hline $\begin{array}{l}\text { Nilai } \\
\text { tertinggi }\end{array}$ & 83,00 & 100,00 & & \\
\hline $\begin{array}{l}\text { Nilai } \\
\text { terendah }\end{array}$ & 35,42 & 73,75 & & \\
\hline
\end{tabular}

Berdasarkan hasil penelitian, sebelum dilaksanakan kegiatan pembelajaran dilaksanakan pretest terlebih dahulu dengan hasil siswa yang dinyatakan tuntas belajar 10 siswa dari 31 siswa. Sedangkan hasil postest mengalami peningkatan yang sangat baik yaitu seluruh siswa dinyatakan tuntas belajar dengan peningkatan (gain) sebesar 0,70. Secara keseluruhan, siswa telah lulus dari hasil posttest bahkan dua siswa mendapatkan skor 100, dan 21 siswa yang tidak tuntas ketika pretes mendapatkan skor lebih dari 70. Hal ini karena siswa merasa terbantu memahami materi dengan menggunakan alat peraga sulingpusling yang dikembangkan, karena salah satu fungsi dari penggunaan alat peraga adalah memberi motivasi kepada siswa untuk lebih giat belajar

Pembelajaran dengan menggunakan alat peraga pada dasarnya sudah memiliki banyak kelebihan diantaranya memberikan motivasi kepada siswa untuk lebih giat belajar, siswa lebih mudah memahami konsep yang dipelajari dan ketrampilan siswa bertambah sehingga lebih aktif belajar. Alat peraga matematika sulingpusling, memiliki kelebihan tersendiri diantaranya, mempermudah siswa dalam memahami materi hubungan sudut keliling dan sudut pusat lingkaran, hubungan beberapa sudut keliling yang menghadap busur yang sama, dan sudut keliling yang menghadap diameter 
sehingga waktu pembelajaran bisa lebih efektif dan efisien.

Dengan berbagai kelebihan tersebut siswa semakin tertarik untuk belajar matematika. Disamping karena memudahkan dalam belajar, alat peraga juga memberikan pengetahuan kepada siswa tentang banyak konsep matematika yang lain, sehingga lebih merangsang siswa dalam belajar matematika.

\section{KESIMPULAN DAN SARAN}

Berdasarkan hasil penelitian dan pembahasan dapat disimpulkan bahwa produk alat peraga sulingpusling, dapat mempermudah siswa memahami konsep yang dipelajarai yaitu materi hubungan sudut keliling dan sudut pusat lingkaran. Alat peraga sulingpusling yang dikembangkan berpengaruh pada keaktifan siswa saat diterapkan pada pembelajaran Matematika pada materi sudut keliling dan sudut pusat lingkaran di SMP N 3 Metro kelas VIII H. Hal ini terlihat dari hasil observasi keaktifan siswa pada pembelajaran menggunakan alat peraga sulingpusling untuk siswa SMP masuk pada kriteria sangat aktif dengan rata-rata persentase $80,86 \%$.

Berdasarkan simpulan di atas, maka saran yang dapat diberikan yaitu, bahwa Inovasi dalam pembelajaran harus selalu dilakukan untuk dapat memotivasi belajar siswa dan memperbaiki kualitas proses pembelajaran, dengan mengembangkan alat peraga sesuai dengan materi yang dipelajari, sehingga hasil belajar siswa bisa maksimal.

\section{DAFTAR PUSTAKA}

Agus, N. A. (2007). Mudah Belajar Matematika untuk Kelas VIII. Jakarta: Pusat Perbukuan.
Annisah, S. (2014). Alat Peraga

Pembelajaran matematika. Jurnal Tarbawiyah.

Guntoro, T. (2010). Penggunaan Alat Peraga dalam Pembelajaran Matematika di SMP. Jurnal EduMat.

Hariastuti, R. M. (2018). Pengembangan Media GEO-SD (Geometri Sketsa Dimensi) Sebagai penunjang Kemampuan Visual Spasial. Aksioma .

Indrawati. (2009). Model pembelajaran terpadu di Sekolah dasar. Jurnal PPPPTK IPA.

Setiyosari. (2012). Metode Penelitian Pendidikan dan Pengembangan. Jakarta: Kencana.

Sugiyono. (2011). Metode Penelitian Pendidikan pendekatan Kuantitatif, Kualitatif, dan $R \& D$. Bandung: Alfabeta.

Sumiati, S. (2009). Visualisasi hukum Perbandingan Volume dan Hipotesis Avogadro dengan menggunakan barang bekas Untuk Meningkatkan Hasil Belajar dan Aktivitas Siswa Kelas X A SMAN 1 Bantaeng. Chemica.

Safitri, M. (2017). Pengembangan Media Pembelajaran Matematika pokok bahasan Segitiga Menggunakan Macro Media Flash Unutk Siswa Kelas VII SMP. Jurnal Pendidikan

Trianto. (2012). Model Pembelajaran Terpadu : Konsep, Strategi dan Implementasinya dalam KTSP. Jakarta: PT Bumi Aksara.

Wallen, F. \&. (1993). How To Design and Evaluate Reaserch In Education. Singapore: McGEAW-HILL.

\section{0 | AKSIOMA}

